\title{
Anti-EGP-2 Immunotoxin MOC31-PE
}

National Cancer Institute

\section{Source}

National Cancer Institute. Anti-EGP-2 Immunotoxin MOC31-PE. NCI Thesaurus. Code C90551.

An immunotoxin consisting of a monoclonal antibody directed against epithelial glycoprotein-2 (EP-2, or epithelial cell adhesion molecule (EpCAM)) conjug ated to the bacterial toxin Pseudomonas exotoxin A (PE) with potential antineoplastic activity. Upon administration of anti-EGP-2 immunotoxin MOC31-PE, the monoclonal antibody moiety targets and binds to EP-2. Upon internalization, the Pseudomonas exotoxin A moiety then inactivates elongation factor 2 (EF-2) through ADP ribosylation, resulting in inhibition of protein synthesis in EP-2-expressing cells. EP-2, a tumor-associated antigen, is overexpressed in a variety of cancer cell types. 